UDC 343.6:341.172

DOI https: / / doi.org/10.32841 / ILA.2020.24.13

\author{
ZHELDAK YA. T., \\ Student at the International Law Faculty \\ Yaroslav Mudryi National Law University
}

\title{
DOMESTIC VIOLENCE AS VIOLATION \\ OF THE EUROPEAN CONVENTION ON HUMAN RIGHTS
}

Summary. Since domestic violence is still a severe issue that targets people across countries, it is important to focus on it as on human rights issue. In this article, the research is conducted from the international human rights law perspective, with domestic violence regarded as a serious problem for all the countries. The author seeks to analyze the provisions of the European Convention on Human Rights in light of protection from domestic violence. The author describes the positive obligations that exist for the members of the Council of Europe regarding domestic violence, as they are key to protecting survivors of domestic violence and preventing it. In this article, domestic violence is analyzed as an issue that can have multiple forms, resulting in different violations of the international human rights law. The paper focuses on the issue of domestic violence as violations of Articles 2, 3, 8 and 14 of the European Convention on Human Rights. In addition, the author describes the existing margin between different provisions of the European Convention on Human Rights that may apply to certain cases. The author also uses numerous landmark cases of the European Court of Human Rights to illustrate the interpretation of domestic abuse in light of the European Convention on Human Rights. In addition, there are some relatively new cases analyzed. In this paper, the issue of domestic violence is consequently researched as a violation of Articles 8, 3,2 and 14, each of the possible approaches illustrated by the relevant case-law. The author aims to illustrate the principles underlying the decisions of the European Court of Human Rights. The article also shows the complexity of the issue, featuring different cases and how the opinion of the European Court of Human Rights may vary depending on the facts of the case, even when they may seem similar.

Key words: domestic violence, European Convention on Human Rights, European Court of Human Rights.

Formulation of the problem. Domestic violence remains a poignant problem for every country, and the European countries are no exception. Even with the ratification of the Council of Europe Convention on preventing and combating violence against women and domestic violence (known as Istanbul Convention) [1], domestic violence is still a common form of gender-based violence and discrimination. Analyzing domestic violence from the international human rights perspective is important, as it marks the severity of the issue.

The failure to provide victims of domestic violence with adequate treatment, protection, and justice has resulted in applications, logged to the Euro- 
pean Court of Human Rights (hereinafter - ECHR or Court). In its decisions, the Court has established a practice of understanding the issue of domestic violence. Since the Court's practice affects, one way or another, the legal system of each member state, it is crucial to analyze the Court's case-law in this area with due scrutiny.

Analysis of recent research and publications. Domestic violence has been an overlooked issue for many years, especially in Ukraine. Only in recent years, the number of related research papers started to grow, including those supported or funded by NGOs. In Ukraine, the topic has been researched by a number of scholars including Kharytonova O. V. [2]. However, Ukrainian scholars tend to focus more on domestic legislation and researching domestic violence as a matter of criminal law.

Also, there are several publications on domestic violence as a matter of human rights law by European authors, including research, conducted by Ramune Jakštienè (Lithuania) in 2014 [3].

Formulating the goals of the article. Since the Court's case-law is an important source of improvement of domestic Ukrainian legislation, a deep analysis of principles and ideas, underlying the Court's decisions on the cases, concerning domestic violence. Even with numerous laws and conventions adopted across Europe, the issue remains delicate and unsolved, so the main purpose of this research is to analyze domestic violence as a violation of several articles of the European Convention on Human Rights (hereinafter - Convention) and to generalize the Court's case-law on domestic violence issues.

Presentation of the main research. Domestic violence is a complex problem, which has several dimensions. They include psychological, social, cultural aspects, as well as legal aspects. Many scholars tend to analyze this issue as a matter of criminal law of a certain country, as it allows to focus on more practical dimensions of domestic violence.

However, it is important to consider combating domestic violence as a part of international human rights law. With domestic violence being a significant component of a vaster problem - gender-based violence and violence against women - it is crucial that the importance of this issue is understood worldwide. For example, the Council of Europe has recognized domestic violence as the most common form of women's rights violations in Europe [4].

Nowadays, many international organizations work on combating domestic violence. With international documents adopted on different levels (The Convention on the Elimination of All Forms of Discrimination against Women (CEDAW) by the United Nations [5] and Istanbul Convention by Council of Europe), domestic violence and violence against women is considered a global problem. These documents require states to create a number of mechanisms, as well as adopt specific legislation, that help eliminate gender-based violence or at least provide survivors with adequate treatment and safety. This work is supported by several funds and organizations, including the United Nations Population Fund (UNFPA), UN Women, etc. 
However, there is a bigger problem that often arises in different counties. This problem is the lack of justice for survivors of domestic violence. While Council of Europe has created a convention that seeks to protect women from gender-based violence, there are still countries that are yet to ratify it (including Ukraine, Great Britain, Hungary, Slovakia and several others - 11 Council of Europe states in total). Thus, women of these countries need other international provisions that can serve as a protection for them - even if they themselves are unaware of such means.

This is where it is important to consider the Convention [6] as the most efficient international document that establishes protection for the survivors seeking justice. Since the ratification of the Convention is essential for a country to be the Council of Europe member, it means that its provisions are able to protect survivors of domestic violence almost in every European country.

When considering domestic violence as a violation of rights established by the Convention, it is important to mention that this issue is covered by several articles. Generally, the applications concerning domestic abuse are lodged to the ECHR regarding Articles 2 (right to life), 3 (prohibition of torture), 8 (right to respect for private and family life) or 14 (prohibition of discrimination). Sometimes the applicants also lodge complaints under Article 6 (right to a fair trial) and Article 13 (right to an effective remedy). As the problem of domestic violence is very complex and each case is rather unique, the applicants usually file an application indicating that several articles of the Convention have been violated.

Speaking of the nature of the obligations that the states have in terms of domestic violence, it is important to note that they are of the positive kind. Even though the primary aim of the Convention is to protect an individual from unlawful actions of the state, the lack of the necessary actions can also constitute a violation of the Convention. It is specifically true for cases involving domestic violence as victims tend to face obstacles while trying to get their case dully investigated and the abuser prosecuted, as well as the governmental bodies (such as the police) believe these cases to be "difficult" [7].

The first time the ECHR formally recognized that a state can be potentially responsible for private acts was in 1998 in Osman v. The United Kingdom [8]. This decision is important as it created a basis for positive obligations for states, including the cases concerning domestic violence. Clearly, perpetrators of domestic abuse are private individuals, but it does not mean that a state cannot be held responsible in the cases, concerning domestic violence.

Article 8 is one of the most common Articles used to lodge a complaint to the Court. While its primary objective is to protect individuals from unlawful intervention in private life by public authorities, the Court has made it clear that domestic violence shall not be regarded as a "private matter" $[9, \S 83]$. This statement, made by Court, establishes an important practice for states. Thus, should the authorities declare a case which involves domestic violence to be a "family matter" and deprive the victim of their right get the perpetrator prosecuted, this will lead to the violation of Article 8 of the Convention. 
The existence of positive obligations was also clarified in $X$ and $Y v$. Netherlands. The Court declared that positive obligations of the states may "involve the adoption of measures designed to secure respect for private life even in the sphere of the relations of individuals between themselves" [10, $\$ 23]$. In this case, a man who raped a mentally disabled girl in a private care facility was not prosecuted because the girl did not take actions herself, and it was her father who lodged the complaint. The Court has found that the states have obligations to interfere when it is necessary to effectively protect the right to private life.

Since Article 8 is quite vast, it is necessary to clarify that the cases regarding domestic violence usually fall within the scope of protection of moral, physical, and psychological integrity. As seen in $X$ and $Y v$. Netherlands, a physical attack can be classified as an infringement of private life. Article 8 is often invoked when there was an incident of ill-treatment, which does not itself reach the severity necessary to invoke Article 3 [11, p. 520]. It is often the case with complaints regarding domestic violence, for example, $A v$. Croatia [12], the applicant was experiencing both physical and verbal abuse, committed by her husband. Even though the applicant has tried to seek protection from authorities, only some of the measures were successful. Others, including compulsory treatment, were not implemented. The husband hired a private detective who discovered the applicant's new address, and the applicant's requests for additional protection were dismissed as the authorities decided she was not in immediate risk. The ECHR found the violation of Article 8 but decided not to examine the complaint under Articles 2, 3, and 13.

With Article 8, it is not always necessary for the violence to be physical, as Hajduova v. Slovakia has shown [13]. The applicant claimed that she was abused by her husband, including death threats after she moved out. Even though the domestic court convicted him, he was required to undergo psychiatric treatment. However, the treatment was not carried out, and the death threats continued after his release from the hospital. The Court has found that the death threats themselves constitute a basis to invoke Article 8, being enough to affect the psychological integrity of the applicant, even though these threats have not materialized into physical abuse $[13, \$ 49]$.

Generally, the Court finds there were violations of Article 8 (in the dimension of state's positive obligations) when there was a lack of effective remedy to protect one family member from another, or when the state fails to adequately protect victims [11, p. 520]. However, it is unlikely for the ECHR to hold there was a violation of this Article when there was a diligent investigation and prosecution, even if the applicant thinks those measures were not severe enough or the sentence was lenient [14].

The balance between positive and negative obligations under Article 8 regarding domestic violence sometimes leads to questioning whether the measures taken by a state to protect victims are not against the rights of others. It may be the case with restraining orders, as this measure often invokes the debate. However, in light of the $A v$. Croatia decision, we can see that in case of domes- 
tic violence, the positive obligations to protect victims should prevail. It is also necessary to mention the recent decision of the ECHR on the case involving domestic violence - Levchuk v. Ukraine [15]. The applicant, who was a victim of domestic violence, tried to enforce the provision of Housing Code which allows for a person to be evicted from the house for systematic inappropriate behavior. Domestic courts have found no reasons for the husband to be evicted, even though they agreed that his behavior was not adequate. The Court held that the national courts were too formalistic in their decisions and the decisions were not in accordance with the state's positive obligation under Article 8.

In this decision, the ECHR emphasized the role of the restraining orders, noting that eviction measure could have potentially compensated the applicant's claims, but the restraining order is more effective when the situation is urgent $[15, \S 82]$.

Therefore, domestic violence is seen by the Court as a violation of Article 8, especially when the threshold of Article 3 was not met. The positive obligations of the states prevail when it comes to the protection of victims of domestic violence.

As we discussed the cases when the Court finds the violation of Article 8, but not Article 3, it is important to focus on the case-law when the ECHR found there was a degrading, inhuman treatment, or torture.

As discussed above, for Article 3 to be invoked, a certain level of hostility and severity of domestic violence is usually required. The assessment of the minimum level of severity is rather relative, and depends on all the circumstances of the case, including the nature and context of the ill-treatment, its effects, duration, etc. [3].

Perhaps the most famous and truly landmark case is Opuz v. Turkey, where the Court has found a violation of Article 3 [16]. The state has failed to protect a wife from her husband, who committed serious physical violence. The Turkish law did not provide for the prosecution of the perpetrator after the applicant withdrew the complaint. Also, the Court found that the small fine imposed and the lack of effective protective actions from the state resulted in a violation of Article 3. Remarkably, the ECHR also declared there was a violation of Article 14, noting that "the applicant has been able to show, supported by unchallenged statistical information, the existence of a prima facie indication that the domestic violence affected mainly women and that the general and discriminatory judicial passivity in Turkey created a climate that was conducive to domestic violence" [16, \$198].

In Opuz v. Turkey, the Court also considered the potential violation of Article 2 regarding the applicant's mother. The applicant's husband killed a woman, and the domestic court mitigated his sentence, substituting life imprisonment with 15 years and 10 months of imprisonment. The reason to mitigate the sentence was that the assault was committed as a result of a "provocation" by the deceased [16, $\$ 53-58]$. The Court found that the Turkish authorities did not display due diligence and failed to protect the applicant's mother, even though she petitioned to the authorities about being in danger and being subjected to 
death threats $[16, \S 149]$. Thus, the Court stated that the state's authorities failed in their positive obligations to safeguard the right to life of the applicant's mother.

Another landmark case, demonstrating the existing margin between violations of Articles 3 and 8, is Valiuliene v. Lithuania, where the Government of Lithuania acknowledged the violation of Article 8, but the Court did not accept it $[17, \S 5]$. The ECHR concluded that the physical injuries of the applicant, as well as damage to her feelings, were severe enough to reach the level of ill-treatment in the meaning of Article $3[17, \S 70]$. This case concerned the inefficiency of relevant authorities, which resulted in the violation of Article 3.

Therefore, the states have positive obligations to protect individuals from ill-treatment or degrading treatment, which is often the case with domestic violence. The Court has confirmed that Article 3 requires states to take measures to ensure that the individuals within the jurisdiction of the state are not subjected to torture, degrading treatment, or ill-treatment, conducted by private individuals $[18, \S 22]$.

The understanding of positive obligations under Article 3 in different cases involving domestic violence is not the same, though. Positive obligations under Article 3 have two dimensions, which sometimes overlap: the obligation to protect against proscribed ill-treatment and the obligation to investigate and to enforce the law [11, p. 274]. In Eremia v. The Republic of Moldova, the state failed to effectively prosecute the perpetrator, who was a police officer. The Court found that the suspension of the criminal investigation against the applicant's husband had the effect of shielding him from criminal liability rather than deterring him from committing further violence against the applicant, resulting in his virtual impunity $[19, \S 65]$.

Thus, it can be seen that the two dimensions of the state's positive obligations under Article 3 often overlap, especially when it comes to domestic violence. The states should not only create a legal framework that prevents and punishes the ill-treatment but also are also required to effectively investigate and prosecute such incidents. These obligations are especially important for cases involving domestic violence since the adoption of the applicable legislation is usually not enough for the perpetrators to be punished.

Even though the interpretation of the Convention's provisions regarding domestic violence is not strict, the Court's practice shows that even a single act of inhuman, degrading treatment can be considered serious enough to invoke Article 3.

Article 2, which protects the right to life, is not the most common provision to be invoked in the cases concerning domestic violence, as deprivation of life is the most severe outcome of the incidents. States have a positive obligation to safeguard the right to life, and the general principles of this obligation arising have been described in Branko Tomašić v. Croatia: "a positive obligation will arise where it has been established that the authorities knew or ought to have known at the time of the existence of a real and immediate risk to the life of an identified individual from the criminal acts of a third party and that they failed to take 
measures within the scope of their powers which, judged reasonably, might have been expected to avoid that risk" [20, $\$ 49-51]$.

Article 2 was applied to the case in Opuz v. Turkey regarding the applicant's mother. $[16, \S 149]$. In another case that involved a record of physical and psychological abuse, Kontrova v. Slovakia, the police failed to fulfil its obligations multiple times, which led to the death of the applicant's children, who were shot by her husband [21, $\$ 14]$. The Court found a violation of Article 2 in this case $[21, \S 55]$, as the death of the minor children were directly linked to the failures of the authorities to prevent this violence.

This paper already has several examples of cases that illustrate the Court's opinion on domestic violence being a form of discrimination (including Opuz v. Turkey, Eremia v. The Republic of Moldova). Nevertheless, it is important to emphasize that the Court often finds a violation of Article 14 when the manner in which the authorities handled the case resulted in a failure to fulfil the positive obligations. For example, in Mudric v. The Republic of Moldova, the Court held there was a violation of Article 3 in conjunction with Article 14 [22]. The applicant complained that the authorities failed to enforce court protection orders. In the Court's opinion, the actions of the authorities were not a result of a simple failure but reflected a discriminatory attitude towards the applicant as a woman $[22, \$ 63]$. Thus, the ECHR found a violation of Article 14 .

When it comes to invoking Article 14 regarding domestic violence cases, prima facie evidence is of particular importance. For example, in Mudric $v$. The Republic of Moldova, the Court found that the findings of the United Nations Special rapporteur on violence against women, its causes and consequences support the impression of discrimination against women in Moldova [22, $\$ 63]$.

There are other cases in which sufficient prima facie evidence was found, too. For example, in Eremia v. The Republic of Moldova, there was a suggestion of a reconciliation by social worker, and the applicant was called "not the first nor the last woman to be beaten by her husband". In addition, there was pressing by police officials to withdraw the application, as well as suspending the proceedings $[19, \$ 89]$. Similarly, the Court has made an important statement in Opuz v. Turkey, where it recognized the violence that the applicant and her mother had to endure as a form of discrimination against women $[16, \$ 200]$.

However, there were cases where the applicant did not produce sufficient prima facie evidence, and the complaint under Article 14 was thus rejected by the Court. In Kalucza v. Hungary, the applicant failed to show different treatment compared to others in similar situations $[23, \S 75]$. If the applicant decides to invoke Article 14, it is essential they produce sufficient prima facie evidence, which may include data from the Committee on the Elimination of Discrimination Against Women, United Nations Special rapporteur on violence against women, case-law, statistics, etc.

Understanding of gender-based violence (including domestic violence) as a form of discrimination is incorporated not only in the ECHR case-law but also on the UN level. General Recommendation No. 19, adopted in 1992 by the 
Committee on the Elimination of Discrimination Against Women, focuses on violence against women. It defines "gender-based violence" as "a form of discrimination" [24].

It is essential to mention that domestic violence is not understood by the Court as an issue that only women can be subjected to. For instance, Article 3, discussed above, applies against men as well as women $[25, \S 50]$. The Court has emphasized numerous times that domestic violence can take various forms, and it is a general problem for all member states. However, it has also noted that women make up an overwhelming majority of victims $[26, \S 71]$.

As seen in many cases, discussed above, the ECHR often finds multiple violations in a case when it comes to domestic violence. It is also common when there are several applicants, for example, a mother and her children. In these cases, the Court may find different provisions of the Convention applicable to each applicant (as in Eremia v. The Republic of Moldova, etc.).

When it comes to domestic violence, the concept of due diligence is a standard. The Court has incorporated this standard by recognition state responsibility for non-state actors in meeting obligations under the Convention [27]. As discussed above, due diligence can be key to preserve the right to life, physical and psychological integrity, as required by the Convention.

Conclusions and prospects for further research. As we can see, the ECHR has confirmed multiple times that the states need to fulfil their positive obligations when it comes to reacting to domestic violence. With the issue of domestic violence being quite complex, the Court examines the cases with scrutiny, applying different provisions of the Convention.

When it comes to finding whether Article 3 or Article 8 was violated in the cases, involving domestic violence, the ECHR decides whether a certain threshold of severity was met. This decision may depend on various aspects.

In numerous cases, the Court has held that women continue to face discrimination when they try to file a complaint to the police or other governmental agencies. Even when there is a sophisticated legal framework to prevent and combat domestic violence, it may be inefficient in certain cases, especially if authorities create obstacles to justice.

As for further research, it is important to focus on a bigger picture: domestic violence and violence against women being a matter of international law. Comparative research illustrating how different countries try to eliminate the obstacles to justice for women may be useful for improving the situation with domestic violence and the response to it.

\section{References:}

1. Council of Europe Convention on preventing and combating violence against women and domestic violence. 2011. URL: https://www.coe.int/en/web/conventions/full-list/-/conventions/rms/090000168008482e (date of access: 25.01 .2021 )

2. Kharytonova O. V. Domestic violence and women's access to justice: legal barriers. Herald of the association of criminal law of Ukraine. Vol 1, No 13 (2020). URL: http://vakp.nlu.edu.ua/article/view/204746/207660 
3. Jakštienè R. Domestic violence in case-law of European Court of Human Rights. Mykolo Romerio universiteto Viešojo saugumo fakultetas. (2014). URL: https://repository.mruni.eu/handle/007/14947

4. Preventing and Combating Violence against Women. Council of Europe. URL: https://www.coe.int/en/web/genderequality/violence-against-women\# \{“16800 160": [0]\}(date of access: 25.01.2021)

5. The Convention on the Elimination of All Forms of Discrimination against Women (CEDAW). 1979. URL: https://www.un.org/womenwatch/daw/cedaw/text/econvention.htm (date of access: 25.01.2021)

6. Convention for the Protection of Human Rights and Fundamental Freedoms. 1950. URL: https://www.echr.coe.int/documents/convention_eng.pdf (date of access: 25.01.2021)

7. Hall M. Prosecuting Domestic Violence: New Solutions to Old Problems? International Review of Victimology, 15(3) (2009). 255-276. URL: https://journals.sagepub.com/doi/abs/10.1177/026975800901500303

8. Osman v The United Kingdom, app. no. 23452/94, 28 October 1998, ECHR (1998). URL: http://hudoc.echr.coe.int/eng?i=001-58257 (date of access: 25.01.2021)

9. Bevacqua and S. v Bulgaria, app. no. 71127/01, 12 June 2008, ECHR (2008). URL: http://hudoc.echr.coe.int/eng?i=001-86875 (date of access: 25.01.2021)

10. X and Y v Netherlands, app. no. 8978/80, 26 March 1985, ECHR (1985). URL: http://hudoc.echr.coe.int/fre?i=001-57603 (date of access: 25.01.2021)

11. Harris, D., O'Boyle, M., Bates, E., Buckley, C. Law of the European Convention on Human Rights. Oxford University Press, $4^{\text {th }}$ edition (2018)

12. A v Croatia, app. no. 55164/08, 14 October 2010, ECHR (2010). URL: http://hudoc.echr.coe.int/eng?i=001-101152 (date of access: 25.01.2021)

13. Hajduova v Slovakia, app. no. 2660/03, 30 November 2010, ECHR (2010). URL: http://hudoc.echr.coe.int/eng?i=001-101945 (date of access: 25.01.2021)

14. MT and ST v Slovakia, app. no. 59968/09, 29 May 2012, ECHR (2012). URL: http://hudoc.echr.coe.int/eng?i=001-111527 (date of access: 25.01.2021)

15. Levchuk v Ukraine, app. no. 17496/19, 3 September 2020, ECHR (2020). URL: http://hudoc.echr.coe.int/eng?i=001-203931 (date of access: 25.01.2021)

16. Opuz v Turkey, app. no. 33401/02, 9 June 2009, ECHR (2009). URL: http://hudoc.echr.coe.int/eng?i=001-92945 (date of access: 25.01.2021)

17. Valiulienè v Lithuania, app. no. 33234/07, 26 March 2013, ECHR (2013). URL: http://hudoc.echr.coe.int/eng?i=001-117636 (date of access: 25.01.2021)

18. A. v The United Kingdom, app. no. 25599/94, 23 September 1998, ECHR (1998). URL: http://hudoc.echr.coe.int/eng?i=001-58232 (date of access: 25.01 .2021 )

19. Eremia v The Republic of Moldova, app. no. 3564/11, 28 May 2013, ECHR (2013). URL: http://hudoc.echr.coe.int/eng?i=001-119968 (date of access: 25.01.2021)

20. Branko Tomašić and Others v Croatia, app. no. 46598/06, 15 April 2009, ECHR (2009). URL: http://hudoc.echr.coe.int/eng?i=001-90625 (date of access: 25.01.2021)

21. Kontrova v Slovakia, app. no. 7510/04, 31 May 2007, ECHR (2007). URL: http://hudoc.echr.coe.int/eng?i=001-80696 (date of access: 25.01 .2021 )

22. Mudric v The Republic of Moldova, app. no. 74839/10, 16 July 2013, ECHR (2013). URL: http://hudoc.echr.coe.int/eng?i=001-122375 (date of access: 25.01.2021)

23. Kalucza v Hungry, app. no. 57693/10, 24 April 2012, ECHR (2012). URL: http://hudoc.echr.coe.int/eng?i=001-110452 (date of access: 25.01.2021)

24. CEDAW Committee: General Recommendation No. 19 on Violence Against Women. 1992. URL: https://www.oursplatform.org/wp-content/uploads/CEDAW-Commit- 
tee-General-Recommendation-19-Violence-against-Women.pdf (date of access: 25.01.2021)

25. Civek v Turkey, app. no. 55354/11, 23 February 2016, ECHR (2016). URL: http://hudoc.echr.coe.int/eng?i=001-161058 (date of access: 25.01.2021)

26. Volodina v Russia, app. no. 41261/17, 9 July 2019, ECHR (2019). URL: http://hudoc.echr.coe.int/spa?i=001-194321 (date of access: 25.01.2021)

27. Hasselbacher L. State Obligations Regarding Domestic Violence: The European Court of Human Rights, Due Diligence, And International Legal Minimum of Protection. Northwestern Journal of International Human Rights. Vol. 8 (2) (2010). URL: https://scholarlycommons.law.northwestern.edu/njihr/vol8/iss2/3

Желдак Я. Т. Домашнє насильство як порушення Європейської конвенції про захист прав людини та основоположних свобод

Анотація. Оскільки домашнє насильство досі залишається серйозною проблемою, від якої потерпають люди в усіх країнах, важливо зосереджуватися на цій проблемі як на порушенні прав людини. У цій статті автор проводить дослідження з погляду міжнародного права прав людини, а домашнє насильство пропонує розуміти як серйозну проблему для всіх країн. У статті автор пропонує проаналізувати положення Європейської конвенції про захист прав людини та основоположних свобод саме у світлі захисту осіб від домашнього насильства. Автор описує позитивні зобов’язання, що існують у країн-членів Ради Європи в контексті домашнього насильства, адже такі позитивні зобов'язання держав $\epsilon$ ключовими у захисті постраждалих від домашнього насильства, а також у його попередженні. У цій статті домашнє насильство аналізується як проблема, яка може мати різні прояви та форми, що призводить порушень різних норм міжнародного права прав людини. Ця стаття фокусується на домашньому насильстві як потенційному порушенні Статей 2, 3, 8 та 14 Європейської конвенції про захист прав людини та основоположних свобод. На додачу автор статті описує відносно тонку та абстрактну межу, яка існує між різними положеннями Європейської конвенції про захист прав людини та основоположних свобод у контексті домашнього насильства, i які з них можуть застосовуватися до конкретних справ. Автор використовує різні важливі рішення Європейського суду з прав людини 3 метою проілюструвати трактування домашнього насильства у світлі Європейської конвенції про захист прав людини та основоположних свобод. Також аналізуються деякі відносно нові справи. У цій статті питання домашнього насильства послідовно досліджено як порушення Статей 8, 3, 2 та 14, також кожен із можливих підходів проілюстровано відповідною практикою Європейського суду з прав людини. Автор має на меті проілюструвати принципи, що покладені в основу винесених рішень Європейського суду з прав людини. Стаття також демонструє складність проблеми домашнього насильства, показуючи різні приклади рішень та те, як позиція Європейського суду з прав людини може різнитися залежно від фактів справи, навіть якщо на перший погляд вони можуть здаватися схожими.

Ключові слова: домашнє насильство, Європейська конвенція про захист прав людини та основоположних свобод, Європейський суд із прав людини. 